\title{
INFLUENCE OF NITROGEN FERTILIZER TREATMENTS ON SOFT WHEAT STARCH
} CHARACTERISTICS.

\author{
C. MASSAUX ${ }^{1}$, M. SINDIC ${ }^{1}$, J. LENARTZ ${ }^{2}$, A.M. PARIDAENS ${ }^{2}$, G. SINNAEVE ${ }^{2}$, \\ B. BODSON ${ }^{3}$, A. FALISSE ${ }^{3}$, P. DARDENNE ${ }^{2}$ and C. DEROANNE ${ }^{1}$ \\ ${ }^{1}$ Gembloux Agricultural University, Technologie des Industries Agro-alimentaires, \\ Passage des Déportés, 2, B-5030 Gembloux, Belgium, Technoalim.gembloux@ulg.ac.be \\ ${ }^{2}$ Walloon Agricultural Research Centre, Dpt Qualité des Productions agricoles, \\ Chaussée de Namur, 24, B-5030 Gembloux, Belgium, Dptqual@cra.wallonie.be \\ ${ }^{3}$ Gembloux Agricultural University, Phytotechnie des Régions tempérées, \\ Passage des Déportés, 2, B-5030 Gembloux, Belgium, Phytot.gembloux@ulg.ac.be
}

\begin{abstract}
Different nitrogen treatments were applied on winter wheat crops during several growing seasons (2002, 2003 and 2005). The starch was isolated and the impact of the nitrogen fertilization on the starch properties was evaluated. The comparison of the three harvest seasons shows globally the same observations. A significant impact of the $\mathrm{N}$-fertilization on the grain yield and flour properties was measured for all studied varieties. The starch damages increased slightly with the N-doses but the other measured starch characteristics tended to be insensitive to applied N-fertilization. These results suggest that protein and starch accumulations in wheat grains are probably independent events.
\end{abstract}

\section{Introduction}

Ideally sown in the middle of October, winter wheat crops are usually fertilized with nitrogen (N) applications varying with the soil type, the soil fertility, the previous crop and the state of the crop. Generally, the $\mathrm{N}$-fertilization is equally distributed over three applications after the winter: the first during tillering, the second at beginning of stem elongation and the third at flag leaf emergence to assure the persistence of the photosynthetically-active flag leaf. Now the tendency is to postpone the first nitrogen application to the third fraction to increase the grain yield of wheat crops (about 2/3 of the dry matter is photosynthesised after the flag leaf stage).

The influence of nitrogen fertilizer treatments on the flour protein content and properties, which correlates with the efficiency on the gluten-starch separation and the gluten yield is well known (Daniel and Triboi, 2000; Boehm et al., 2004). But the literature is very scarce on the effect of this agronomic factor on the starch characteristics (Kelfkens and Hamer, 1991). Consequently, it is interesting to determine whether increasing $\mathrm{N}$ fertilizer rates induce variations in starch characteristics.

\section{Wheat samples}

The impact of N-fertilization was investigated for wheat varieties Corvus and Folio in 2002 and 2003, and for wheat varieties Deben and Meunier in 2005. Meunier is associated with the highest bread-making quality, Corvus and Folio with a good bread-making quality and Deben with a low bread-making quality. Moreover, Folio is known to be susceptible to preharvest sprouting. Wheat samples were grown in the experimental field at Lonzée (Belgium), normally sown in October and harvested in August. Two fungicide treatments were applied, good weed and insect control were achieved in all trials by applying appropriate herbicides and insecticides.

Nitrogen was applied under solid form as $\mathrm{NH}_{4} \mathrm{NO}_{3}$. The total amount of $\mathrm{N}$-fertilization applied to the wheat varieties ranged from 0 to $300 \mathrm{~kg} \mathrm{~N} / \mathrm{ha}$. These amounts were distributed over three split applications. Each sample was grown in four different plots of $16 \mathrm{~m}^{2}$ in a fully randomised block design. Wheat kernels from 4 different plots were mixed to reduce location effect and to increase the homogeneity of the samples. 


\section{Starch isolation}

Wheat grains were milled with a Quadrumat senior mill (Brabender, Duisberg, Germany).Starches were isolated by the 'Batter' procedure from $2.0 \mathrm{~kg}$ of white flour (Fig. 1).

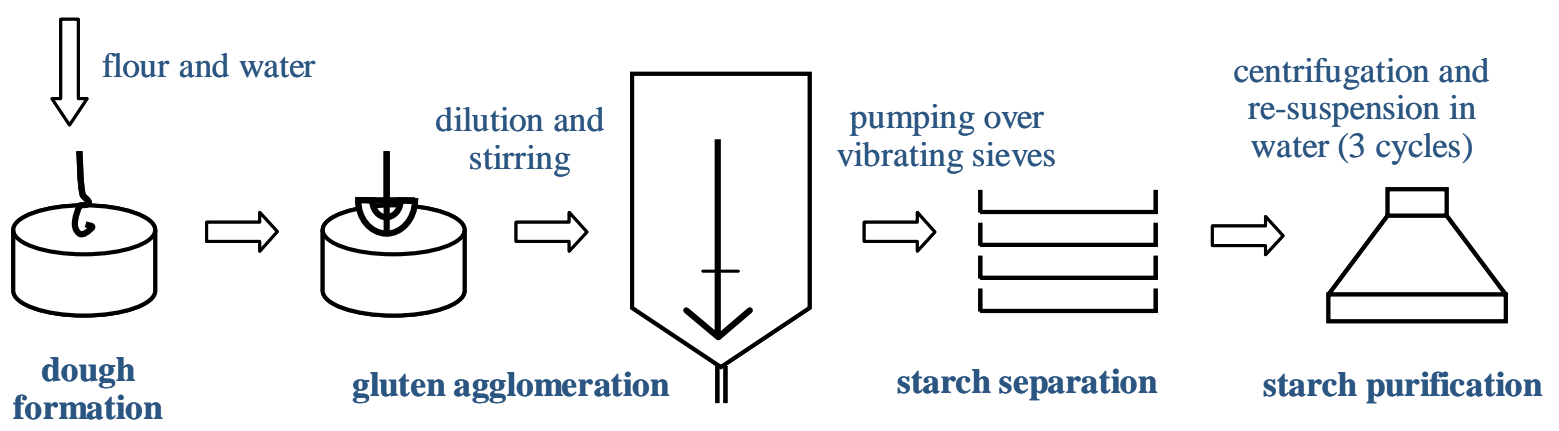

Figure 1: Starch isolation by the Batter procedure

\section{Results}

Table I shows the influence of N-doses and N-split applications on grain yield, protein content, flour and starch characteristics.

Table 1: The influence of N-dose on grain yield, protein content (by NIRS), flour and starch characteristics

\begin{tabular}{|c|c|c|c|c|c|c|c|c|c|}
\hline $\begin{array}{l}\text { Wheat } \\
\text { variety }\end{array}$ & $\begin{array}{l}\text { N-dosage } \\
\text { (kg N/ha) }\end{array}$ & $\begin{array}{c}\mathrm{N} \text {-split } \\
\text { applications }\end{array}$ & $\begin{array}{c}\text { Grain yield } \\
\text { (kg/ha) }\end{array}$ & $\begin{array}{c}\text { Protein } \\
\text { content } \\
(\%) \\
\end{array}$ & $\begin{array}{c}\text { Water } \\
\text { absorption } \\
\text { of flour (\%) }\end{array}$ & $\begin{array}{c}\text { Damaged } \\
\text { starch } \\
\text { (CDU) } \\
\end{array}$ & $\begin{array}{c}\text { Starch } \\
\text { B-granules } \\
\text { content (\%) } \\
\end{array}$ & $\begin{array}{c}\text { Starch } \\
\text { viscosity at } \\
95^{\circ} \mathrm{C}(\mathrm{BU}) \\
\end{array}$ & $\begin{array}{c}\text { Starch } \\
\text { viscosity at } \\
50^{\circ} \mathrm{C}(\mathrm{BU}) \\
\end{array}$ \\
\hline \multicolumn{10}{|l|}{2002} \\
\hline \multirow[t]{5}{*}{ CORVUS } & 0 & $0-0-0$ & 5942 & 9.2 & 52.0 & 17.9 & 23.6 & 2.92 & 472 \\
\hline & 150 & $50-50-50$ & 9572 & 10.9 & 5.3 .5 & 18.4 & 22.7 & 301 & 472 \\
\hline & 200 & $100-100-0$ & 89.91 & 11.3 & 53.5 & 18.8 & 21.6 & 29.5 & 467 \\
\hline & 200 & $0-100-100$ & 9448 & 11.7 & 5.3 .5 & 18.4 & 22.1 & 30.3 & 479 \\
\hline & 300 & $100-100-100$ & 8805 & 12.2 & 53.5 & 18.8 & 22.0 & 2.97 & 470 \\
\hline \multirow[t]{5}{*}{ FOLIO } & 0 & $0-0-0$ & 5778 & 10.0 & 57.5 & 20.3 & 21.3 & 307 & 450 \\
\hline & 150 & $50-50-50$ & 939.9 & 11.4 & 58.0 & 20.0 & 22.4 & 302 & 448 \\
\hline & 200 & $100-100-0$ & 9388 & 12.1 & 58.5 & 20.1 & 22.3 & 296 & 440 \\
\hline & 200 & 0-100-100 & 9151 & 12.7 & 59.5 & 19.9 & 24.4 & 305 & 446 \\
\hline & 300 & $100-100-100$ & 9214 & 13.1 & 60.0 & 19.5 & 24.1 & 303 & 452 \\
\hline \multicolumn{10}{|l|}{2003} \\
\hline \multirow[t]{5}{*}{ CORVUS } & 0 & $0-0-0$ & 5182 & 8.2 & 50.5 & 18.0 & 20.9 & 284 & 453 \\
\hline & 150 & $50-50-50$ & 10042 & 9.6 & 53.5 & 18.5 & 20.7 & 290 & 457 \\
\hline & 200 & $100-100-0$ & 10164 & 10.2 & 53.5 & 18.6 & 21.3 & 287 & 465 \\
\hline & 200 & $0-100-100$ & 9.923 & 11.0 & 54.5 & 19.4 & 20.1 & 280 & 468 \\
\hline & 300 & $100-100-100$ & 10162 & 11.9 & 55.0 & 19.3 & 21.4 & 281 & 461 \\
\hline \multirow[t]{5}{*}{ FOL.IO } & 0 & $0-0-0$ & 5206 & 9.9 & 58.5 & 21.5 & 22.5 & 277 & 465 \\
\hline & 150 & $50-50-50$ & 9493 & 11.0 & 61.5 & 21.6 & 23.8 & 275 & 467 \\
\hline & 200 & $100-100-0$ & 9920 & 11.9 & 61.5 & 21.6 & 21.3 & 278 & 458 \\
\hline & 200 & 0-100-100 & 9872 & 12.3 & 62.5 & 21.7 & 23.7 & 275 & 465 \\
\hline & 300 & $100-100-100$ & 10416 & 12.9 & 63.5 & 21.6 & 21.6 & 275 & 465 \\
\hline \multicolumn{10}{|l|}{2005} \\
\hline \multirow[t]{3}{*}{ DEBEN } & 110 & $50-60-0$ & 10726 & 9.2 & 46.0 & 14.4 & 22.4 & 269 & 426 \\
\hline & 185 & $50-60-75$ & 11256 & 9.9 & 46.5 & 15.5 & 20.6 & 270 & 430 \\
\hline & 215 & $0-60-155$ & 11586 & 10.5 & 47.0 & 16.0 & 18.7 & 273 & 437 \\
\hline \multirow[t]{3}{*}{ MEUNIER } & 110 & $50-60-0$ & 9617 & 10.2 & 48.0 & 14.1 & 16.8 & 333 & 447 \\
\hline & 185 & $50-60-75$ & 10673 & 12.0 & 50.0 & 15.6 & 15,4 & 328 & 439 \\
\hline & 215 & $0-60-155$ & 103.93 & 12.9 & 51.0 & 15.8 & 14.7 & 3.33 & 448 \\
\hline
\end{tabular}


$\mathrm{N}$-fertilization is well known to increase grain yields and protein levels. These results are also observed in our trials for all the varieties and the growing seasons. For example, grain yields for Folio (2003) ranges from 5200 to $10400 \mathrm{~kg} / \mathrm{ha}$, and protein content vary from 9.9 to $12.9 \%$ with the increase of the $\mathrm{N}$-doses. Water absorption of flour, evaluated using a farinograph (Brabender, Duisberg, Germany), increases also with the N-doses.

Damaged starch values were determined amperometrically by the Chopin SD4 method (Villeneuve-la-Garenne, France). Starch damages increase slightly with the N-doses for all the varieties except for Folio. This variety is associated with a very hard wheat grain, inducing always high values of starch damages during milling. The 2005 results show a more important increase of the starch damage, associated with the increased $\mathrm{N}$-doses and the later $\mathrm{N}$ applications.

Granule size distribution of starches was determined by using a laser granulometer (Malvern, Worcestershire, UK). Different tendencies (increase, constancy or decrease) are observed as function of the varieties and the growing seasons. From these results, we can not conclude that the volume percentages of the small B-granules are influenced by the $\mathrm{N}$-doses.

Starch viscosity properties were evaluated with a micro visco-amylograph (Brabender, Duisberg, Germany). Starch suspensions, prepared with addition of $2 \mathrm{mM} \mathrm{AgNO}_{3}$ to remove the effect of alpha-amylase, were subjected to a time-temperature profile (increase to $95^{\circ} \mathrm{C}$ in $10 \mathrm{~min}$, holding at $95^{\circ} \mathrm{C}$ for $10 \mathrm{~min}$ and decrease to $50^{\circ} \mathrm{C}$ in $10 \mathrm{~min}$ ). For a same variety, the viscosity values, measured at 95 and $50^{\circ} \mathrm{C}$, do not vary significantly with the $\mathrm{N}$-doses. It is interesting to note that the starches isolated from wheat samples grown with 0 or $300 \mathrm{~kg} \mathrm{~N} /$ ha present the same viscosity behavior.

\section{Conclusion}

Grain nitrogen level is one of the main quality parameters of wheat grains. N-fertilization is known to increase grain yield and grain protein content. Although large variations are observed on the grain and protein parameters, the starch properties tend to be globally insensitive to

applied $\mathrm{N}$-fertilization, suggesting that protein and starch accumulations in wheat grains are probably independent events, controlled and influenced by different factors.

\section{Acknowledgments}

This research project is financed by Ministère de la Région Wallonne, Direction générale de l’Agriculture, Direction de la Recherche.

\section{Literature cited}

Boehm, D.J., Berzonsky, W.A., and Bhattacharya, M. 2004. Influence of nitrogen fertilizer treatments on spring wheat (Triticum aestivum L.) flour characteristics and effect on fresh and frozen dough quality. Cereal Chem. 81: 51-54.

Daniel, C., and Triboi, E. 2000. Effects of temperature and nitrogen nutrition on the grain composition of winter wheat : Effects on gliadin content and composition. J. Cereal Sci. 32:45-56.

Kelfkens, M., and Hamer, R.J. 1991. Agronomic factors related to the quality of wheat for the starch industry. Part II : Nitrogen fertilisation and overall conclusions. Starch/Stärke 43:344-347. 